Analitika: Jurnal Magister Psikologi UMA, Vol. 11 (2) Desember (2019)

ISSN: 2085-6601 (Print), ISSN: 2502-4590 (Online)

DOI: http://dx.doi.org/analitika.v11i1.3001

ANALITIKA

Jurnal Magister Psikologi UMA

Available online http://ojs.uma.ac.id/index.php/analitika

\title{
Peran Keluarga dalam Upaya Pencegahan Perilaku Seks Pranikah Remaja di Palembang
}

\section{The Role of Family in Prevention Adolescent Premarital Sexual Behavior in Palembang}

\author{
Yeni Anna Appulembang1), Nur Alam Fajar2), Angeline Hosana Zefany Tarigan ${ }^{3)}$ \\ 1) 3) Program Studi Psikologi, Fakultas Kedokteran, Universitas Sriwijaya, Indonesia \\ 2) Program Studi Promkes, Fakultas Kesehatan Masyarakat, Universitas Sriwijaya, Indonesia
}

Diterima: 21 Oktober 2019, disetujui: 28 Desember 2019, dipublish: 30 Desember 2019

*Corresponding author: E-mail: yenianna@fk.unsri.ac.id

\begin{abstract}
Abstrak
Seks pranikah pada remaja merupakan suatu fenomena yang semakin marak terjadi. Keluarga khususnya orangtua ikut berperan dalam upaya mencegah hubungan seksual pranikah. Penelitian ini bertujuan untuk mengetahui peran fungsi keluarga dalam upaya mencegah perilaku Seks Pranikah Remaja di Kota Palembang. Penelitian ini merupakan studi kausal kompartif. Subyek yang digunakan adalah siswa/siswi dari SMA dan SMK swasta X yang ada di kota Palembang. Jumlah subyek yang digunakan adalah 144 orang, subyek dipilih dengan menggunakan teknik pengambilan sampel purposive sampling. Pada penelitian ini, alat ukur yang digunakan ada dua yaitu fungsi keluarga dan perilaku seksual. Pada penelitian ini, peneliti melakukan uji regresi dengan menggunakan simple regression dan menunjukkan nilai F hitung sebesar 0,001 dengan nilai p sebesar 0,971 >0,05, artinya tidak terdapat peranan fungsi keluarga terhadap perilaku seksual pranikah remaja. Dengan demikian dapat sarankan agar diteliti lebih lanjut mengenai faktor lain yang berperan terhadap perilaku seksual yang dilakukan oleh remaja.
\end{abstract}

Kata kunci: Fungsi keluarga, perilaku seks pranikah, remaja

\begin{abstract}
Sex premarital behavior in adolescent is a widespread phenomenon. The role of family specially parents very important in preventing premarital sexual behavior. This research aims to determine family function on premarital sexual behavior prenvention among adolescent in Palembang Nort Sumatera. This study was used Causal comparative study and a sample 144 in high school students was selected through purposive sampling. This research was used two research tolls such as the role family was used Family Asessment Device (FAD) and premarital sexual behavior. The result in this research found $F$ values is 0,001 and $p$ values 0,971 >0,05, it means there is no family function on premarital sexual behavior prenvention among adolescent in Palembang Nort Sumatera. Considering the result of the research, the recommendation can be doing the next research about premarital sexual behavior with other factor.
\end{abstract}

Keywords: Family function, premarital sexual, adolescent

How to Cite: Appulembang, Y. A., Nur, A. F. \& Angeline H. Z. T. (2019), Peran Keluarga dalam Upaya Pencegahan Perilaku Seks Pranikah Remaja di Palembang, Analitika: Jurnal Magister Psikologi UMA, 11 (2): $151-158$ 


\section{PENDAHULUAN}

Seks pranikah pada remaja merupakan suatu fenomena yang semakin marak terjadi di berbagai Negara dan salah satunya di Indonesia. Berdasarkan catatan lembaga BKKBN, 46\% remaja berusia 15-19 tahun sudah berhubungan seksual. Hasil penelitian yang dilakukan oleh Komnas tahun 2012 tentang perilaku seks di kalangan remaja SMP dan SMA yang dilakukan di 17 kota besar di Indonesia menyebutkan bahwa dari 4.726 responden, 97\% mengatakan pernah menonton pornografi, 93,7\% mengaku sudah tidak perawan, serta $21,26 \%$ sudah pernah melakukan aborsi (Rahmawati \& Devi, 2016).

Berdasarkan hasil survei Komnas anak bekerja sama dengan Lembaga Perlindungan Anak (LPA) di 12 provinsi pada tahun 2007 terungkap sebanyak 93,7\% siswa SMP dan SMU yang disurvei mengaku pernah melakukan ciuman, petting, dan oral seks (Hasibuan, Dewi \& Huda, 2015).

Perilaku seks bebas pada remaja terjadi dibeberapa Kota di Indonesia termasuk Kota Palembang. Berdasarkan data dari Balitbang Pemerintah Kota Palembang tahun 2011 tercatat ada 35\% pelajar dan mahasiswa pernah melakukan seks bebas (Nurhayati, Fajar \& Yeni, 2017).

Rentang usia remaja yang melakukan seks pranikah berkisar antara 13 - 18 tahun (Rahmawati et al., 2008). Masa remaja merupakan masa transisi dari anak-anak ke dewasa dimana usia remaja dimulai dari 11 tahun sampai dengan 22 tahun (Santrock, 2009).

Pada usia ini, remaja memasuki masa produktif dan usia subur artinya remaja secara fisiologis telah mencapai kematangan organ-organ reproduksi, baik remaja lakilaki maupun remaja wanita. Kematangan organ reproduksi mendorong individu untuk melakukan hubungan sosial baik dengan sesama jenis maupun dengan lawan jenis (Triningtyas, 2017).

Berdasarkan hasil survey nasional, menunjukkan bahwa alasan yang menyebabkan remaja melakukan hubungan seks adalah: (1) pasangan laki-laki atau perempuan mendesak; (2) beranggapan bahwa dirinya sudah siap; (3) mereka ingin dicintai; (4) mereka tidak ingin diolok-olok karena masih perjaka/perawan (Triningtyas, 2017).

Pengalaman seksual dikalangan remaja biasanya terjadi dalam konteks hubungan pacaran karena pacaran akan menghadapkan remaja dengan kondisi yang meningkatkan pengalaman seksual mereka (Wartati, 2012).

Perilaku seksual pranikah adalah kegiatan seksual yang melibatkan dua orang yang saling menyukai atau saling mencintai, yang dilakukan sebelum perkawinan. Seks bebas atau dalam bahasa populernya disebut extra-martial intercourse atau kinky-sex merupakan bentuk pembebasan seks yang dipandang tidak wajar (Banun dalam Rahadi, 2017). Bentuk-bentuk perilaku seksual yang biasa dilakukan adalah (1) kissing atau perilaku berciuman, mulai dari ciuman ringan sampai deep kissing, (2) necking atau perilaku mencium daerah sekitar leher pasangan, (3) petting atau segala bentuk kontak fisik seksual berat tapi tidak termasuk intercourse, baik itu light petting (meraba payudara dan alat kelamin pasangan) atau hard petting (menggosokkan alat kelamin sendiri ke alat kelamin 
pasangan, baik dengan berbusana atau tanpa busana), dan (4) intercourse atau penetrasi alat kelamin pria ke alat kelamin wanita (Susanti, 2013).

Aspek-aspek perilaku seksual bebas yaitu: (1) berfantasi seksual merupakan perilaku membayangkan dan mengimajinasikan aktivitas seksual yang bertujuan untuk menimbulkan perasaan erotisme. Fantasi seksual ini biasanya didapatkan individu dari media atau objek yang dapat meningkatkan dorongan seksual; (2) pegangan tangan, aktivitas ini tidak terlalu menimbulkan rangsangan seksual yang kuat namun biasanya muncul keinginan untuk mencoba aktivitas lain; (3) cium kering, berupa sentuhan pipi dengan pipi atau pipi dengan bibir; (4) cium basah, berupa sentuhan bibir ke bibir sampai dengan leher; (5) meraba, merupakan kegiatan bagian-bagian sensitif rangsang seksual seperti leher, dada, paha, alat kelamin; (6) berpelukan, aktivitas ini menimbulkan perasaan tenang, aman, nyaman, disertai rangsangan seksual ( terutama bila mengenai daerah aerogen/sensitif); (7) masturbasi ( wanita) atau onami ( laki-laki), adalah perilaku merangsang organ kelamin untuk mendapatkan kepuasan seksual; (8) Oral Sex, merupakan aktivitas seksual dengan cara memasukkan alat kelamin ke dalam mulut lawan jenis; (9) Petting, merupakan seluruh aktivitas non intercourse (hingga menempelkan alat kelamin); (10) Intercourse (senggama), merupakan aktivitas seksual dengan memasukkan alat kelamin laki-laki ke dalam alat kelamin wanita (Adikusuma et al; Bungin; Rahardjo; Sarwono \& Samsidar;
Purnawan dalam Mertia, Hidayat \& Yuliadi, 2011).

Salah satu penyebab terjadinya perilaku seksual pada remaja adalah pengawasan dan perhatian orang tua yang longgar. Berdasarkan hasil penelitian yang dilakukan oleh Nurhayati, Fajar., \& Yeni, 2017 menunjukkan bahwa orangtua memberikan fasilitas kepada anak seperti handphone, laptop, fasilitas internet di rumah. Fasilitas yang disediakan oleh orangtua dapat memudahkan remaaja melakukan rangsangan seksual (Nursal, dalam Haryani, Wahyuningsih \& Haryani, 2015). Kurangnya perhatian orang tua berdampak pada pergaulan bebas dan salah satunya melakukan hubungan suami istri di luar nikah (Rochaniningsih, 2014).

Orangtua memegang peranan penting untuk mencegah hubungan seksual pranikah (Gustina, 2017). Keterlibatan keluarga dalam perkembangan anak sangat penting khususnya orangtua. Orangtua terkadang begitu sibuk dengan kegiatannya sendiri tanpa mempedulikan bagaimana perkembangan anak-anaknya. Orangtua cenderung hanya memikirkan kebutuhan lahiriah anaknya dengan bekerja keras tanpa mempedulikan bagaimana anak-anaknya tumbuh dan berkembang. Oleh karena itu, perlu diketahui lebih mendalam berbagai penjelasan mengenai fungsi (Rochaniningsih, 2014).

Fungsi keluarga terdiri atas (6) dimensi yaitu pemecahan masalah, komunikasi, peran, responsivitas afektif, keterlibatan afektif, kontrol perilaku. Dimensi pertama yaitu pemecahan masalah, dimensi ini merujuk kepada kemampuan keluarga untuk memecahkan masalah pada setiap level 
sehingga dapat menjaga fungsi keluarga tetap efektif. Dimensi kedua yaitu, komunikasi. Pada dimensi ini lebih berfokus kepada komunikasi secara verbal yang lebih dapat diukur. Dimensi ketiga yaitu peran. Pada dimensi ini terdapat peran dalam keluarga seperti peyediaan sumber daya (penyediaan uang, makanan, pakaian dan tempat tinggal, adanya perawatan dan dukungan (penyediaan kenyamanan, kehangatan, rasa aman dan dukungan untuk anggota anggota keluarga), adanya kepuasan seksual dewasa (pasangan suami istri secara personal merasakan kepuasan dalam hubungan seksual satu sama lain), adanya pengembangan pribadi (mendukung anggota keluarga dalam mengembangkan keterampilan ppribadi seperti perkembangan fisik, emosi, sosial dan pendidikan anak serta pengembangan karir dan perkemmbangan sosial dewasa), adanya pemeliharaan dan pengelolaan sistem keluarga (melibatkan teknik tindakan yang dibutuhkan untuk mempertahankan standar keluarga seperti pengambilan keputusan, batasan dan fungsi keanggotaan dalam keluarga, implementasi dan kontrol perilaku, pengaturan keuangan rumah tangga dan hal yang berkaitan dengan pengasuhan dan kesehatan keluarga). Dimensi keempat yaitu responsivitas afektif, yaitu kemampuan berespon terhadap stimulus yang ada dengan kualitas dan kuantitas perasaan yang tepat. Dimensi kelima yaitu keterlibatan afektif merupakan sejauh mana anggota keluarga menunjukkan ketertarikan dan penghargaan kepada aktivitas dan minat anggota keluarga lainnya. Dimensi keenam yaitu kontrol perilaku, mengenai pola yang diadopsi oleh keluarga untuk menangani perilaku anggota keluarga dalam tiga area yaitu situasi yang membahayakan secara fisik, situasi yang melibatkan pemenuhan kebutuhan dan dorongan psikologis, situasi yang melibatkan perilaku sosialiasi interpersonal baik diantara anggota keluarga maupun dengan oranglain di luar keluarga (Epstein et all, 2003 dalam Pratiwi, A.B.R, 2014).

\section{METODE PENELITIAN}

Penelitian ini merupakan studi kausal kompartif. Tujuan Penelitian ini melakukan pengujian mengenai peranan fungsi keluarga dalam upaya mencegah perilaku seks pranikah remaja di kota Palembang. Subyek yang digunakan adalah siswa/siswi dari SMA dan SMK swasta $X$ yang ada di kota Palembang. Jumlah subyek yang digunakan adalah 144 orang, subyek dipilih dengan menggunakan teknik pengambilan sampel purposive sampling. Adapun karakteristik subyek penelitian adalah siswa/I yang masih aktif dibangku SMA/SMK, berusia 14-19 tahun.

Pada penelitian ini, alat ukur yang digunakan ada dua yaitu fungsi keluarga dan perilaku seksual. Pada alat ukur fungsi keluarga menggunakan Family Asessment Device (FAD), yang dikembangkan oleh Epstein et al. (1983 dalam Pratiwi, 2014). Alat ukur ini terdiri atas enam (6) dimensi yaitu pemecahan masalah, komunikasi, peran, responsivitas afektif, keterlibatan afektif, dan kontrol perilaku. Alat ukur pada fungsi keluarga memiliki 42 butir pernyataan dengan skala Likert yang dibagi menjadi empat (4) pilihan yaitu $1=($ STS $)$ Sangat Tidak Setuju, 2 = (TS) Tidak Setuju, $3=$ (S) Setuju, dan $4=$ (SS) Sangat Setuju. 
Alat ukur kedua adalah perilaku seksual. pada alat ukur kedua ini, peneliti mengkonstruk alat ukur tersebut dengan mengacu kepada 10 aspek perilaku seksual yaitu Aspek-aspek perilaku seksual bebas yaitu: (1) berfantasi seksual; (2) pegangan tangan; (3) cium kering; (4) cium basah; (5) meraba; (6) berpeluka; (7) masturbasi ( wanita) atau onami ( laki-laki); (8) Oral Sex; (9) Petting; (10) Intercourse (senggama). Alat ukur perilaku seksual terdiri atas 43 butir pernyataan dengan menggunakan skala Likert yang dibagi menjadi lima (4) pilihan yaitu 1= (STS) Sangat Tidak Setuju, $2=(\mathrm{TS})$ Tidak Setuju, $3=(\mathrm{S})$ Setuju dan $4=$ (SS) Sangat Setuju.

\section{HASIL DAN PEMBAHASAN}

Berdasarkan hasil analisis data dengan menggunakan statistik deskriptif maka diperoleh hasil sebanyak 44 subyek (30,6\%) pernah melakukan dan 100 subyek (69,4\% ) tidak pernah melakukan perilaku seksual pranikah. Untuk lebih detail dapat dilihat pada gambar berikut ini:

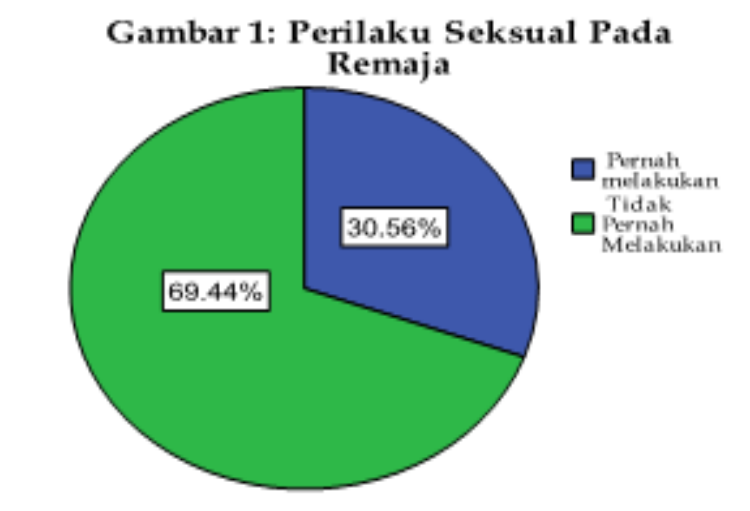

Peneliti juga melakukan analisis pada setiap aspek perilaku seksual pranikah. Berikut ini akan dijelaskan lebih detail.

$$
\text { Pada aspek fantasi seksual }
$$
menunjukkan bahwa terdapat 71 subyek
(49,3\%) pernah melakukan dan 73 subyek $(50,7 \%)$ tidak pernah melakukan. Pada aspek berpegangan tangan menunjukkan bahwa terdapat 45 subyek $(31,3 \%)$ pernah melakukan dan 99 subyek (68,8\%) tidak pernah melakukan.

Pada aspek cium kering menunjukkan hasil 52 subyek $(36,1 \%)$ pernah melakukan dan 92 subyek $(63,9 \%)$ tidak pernah melakukan. Pada aspek cium basah menunjukkan terdapat 25 subyek $(17,4 \%)$ pernah melakukan dan 119 subyek ( 82,6\%) tidak pernah melakukan.

Pada aspek meraba menunjukkan terdapat 26 subyek $(18,1 \%)$ pernah melakukan, 118 subyek (81,9\%) tidak pernah melakukan. Pada aspek berpelukan menujukkan terdapat 37 subyek $(25,7 \%)$ pernah melakukan dan 107 subyek (74,3\%) tidak pernah melakukan.

Pada aspek masturbasi menunjukkan terdapat 22 subyek $(15,3 \%)$ pernah melakukan dan 122 subyek (84,7\%) tidak pernah melakukan. Pada aspek oral sex menunjukkan terdapat 19 subyek ( $13,2 \%)$ pernah melakukan dan 125 subyek $(86,8 \%)$ tidak pernah melakukan. Pada aspek petting menunjukkan terdapat 18 subyek $(12,5 \%)$ pernah melakukan dan 126 subyek ( 87,5\%) tidak pernah melakukan. Pada aspek intercourse menujukkan terdapat 22 subyek ( $15,3 \%$ ) pernah melakukan dan 122 subyek ( 84,6\%) tidak pernah melakukan.

Hasil penelitian yang dilakukan oleh (Afrilyanti, Herlina, 2015) menunjukkan bahwa terdapat 29,2\% yang setuju untuk berpegangan tangan dengan lawan jenis, terdapat 2,6\% yang setuju untuk melakukan necking dengan lawan jenis, terdapat $4,7 \%$ yang setuju pada perilaku berpelukan 
dengan lawan jenis, terdapat $0,4 \%$ yang setuju melakukan petting, terdapat 0,4\% yang setuju melakukan oral sex dan $0,4 \%$ yang setuju melakukan sexual intercourse. Penelitian yang dilakukan oleh (Putra, Ratep, \& Westa, 2014) menunjukkan bahwa terdapat $66,9 \%$ pernah melakukan kissing, 25,7\% pernah melakukan necking, 31\% pernah melakukan meraba, 14,0\% pernah melakukan petting, 5,9\% pernah melakukan oral sex dan 14,7\% pernah melakukan intercourse.

Peneliti juga melakukan uji analisis desriptif mengenai fungsi keluarga dan menemukan bahwa terdapat 80 subyek (55,6\%) yang tergolong pada kategori tinggi dan 64 subyek $(44,4 \%)$ yang tergolong rendah. Untuk lebih detail dapat dilihat pada tabel 1 berikut

Tabel 1 Perilaku Seksual Pranikah Pada Setiap Aspek

\begin{tabular}{lll}
\hline Aspek & Melakukan & $\begin{array}{l}\text { Tidak } \\
\text { Melakukan }\end{array}$ \\
\hline $\begin{array}{l}\text { Fantasi seksual } \\
\text { Berpegangan }\end{array}$ & $71(49,3 \%)$ & $73(50,7 \%)$ \\
tangan & $99(68,8 \%)$ \\
Cium kering & $52(36,1 \%)$ & $92(63,9 \%)$ \\
Cium basah & $25(17,4 \%)$ & $119(82,6 \%)$ \\
Meraba & $26(18,1 \%)$ & $118(81,9 \%)$ \\
Berpelukan & $37(25,7 \%)$ & $107(74,3 \%)$ \\
Masturbasi & $22(15,3 \%)$ & $122(84,7 \%)$ \\
Oral sex & $19(13,2 \%)$ & $125(86,8 \%)$ \\
Petting & $18(12,5 \%)$ & $126(87,5 \%)$ \\
Intercourse & $22(15,3 \%)$ & $122(84,6 \%)$ \\
\hline
\end{tabular}

Berdasarkan hasil analisis data menggunakan statistika deskriptif mengenai fungsi keluarga maka diperoleh hasil bahwa terdapat 80 subyek ( $55,6 \%$ ) yang tergolong pada kategori tinggi dan 64 subyek (44,4\%) yang tergolong rendah. Namun berdasarkan hasil penelitian yang dilakukan oleh ( Putra, Ratep, \& Westa, 2014) menemukan terdapat
84 subyek (61,8\%) fungsi keluarga berkategori kurang berfungsi dan 52 subyek $(38,2 \%)$ yang berkategori baik.

Peneliti juga melakukan uji regresi dengan menggunakan simple regression dan menunjukkan nilai $F$ hitung sebesar 0,001 dengan nilai p sebesar $0,971>0,05$, artinya tidak terdapat peranan fungsi keluarga terhadap perilaku seksual pranikah remaja.

\section{SIMPULAN}

Berdasarkan hasil penelitian diperoleh bahwa tidak terdapat peranan keluarga terhadap perilaku seksual pranikah pada remaja.

Hasil penelitian ini didukung oleh Santrock, 2011 menyatakan bahwa Remaja biasanya mengutamakan peergroup sahabat mereka daripada peran dari orang tua. Remaja seolah lepas dari peran orangtua dan lebih mandiri dalam melakukan keputusan sendiri. Mereka memiliki keinginan yang kuat untuk dapat mandiri dan memiliki tanggung jawab pribadi terhadap perilaku sendiri. Papalia, Olds \& Feldman, (2009) juga menambahkan bahwa faktor yang mempengaruhi aktivitas seksual pada remaja adalah persepsi dari norma kelompok teman sebaya.

Penelitian ini didukung hasil penelitian yang dilakukan oleh (Afrilyanti1, Herlina2, 2015) menunjukkan bahwa tidak ada pengaruh yang signifikan antara fungsi keluarga dengan perilaku seksual pranikah. Artinya perilaku seksual tidak hanya dipengaruhi oleh fungsi keluarga tetapi dapat disebabkan oleh faktor yang lain. Sama seperti yang diungkapkan oleh Rochaniningsih, (2014) bahwa peran dan fungsi keluarga telah mengalami pergeseran pada masyarakat modern. Peran dan fungsi keluarga sebagai 
lembaga sosialisasi dan afeksi telah mengalami perubahan. Hal ini menyebabkan terganggunya proses sosialisasi anak dalam keluarga. Oleh karena itu saat ini banyak anak remaja yang berperilaku menyimpang, dan sebagian besar penelitian mengindikasikan telah terjadi pergaulan bebas (sex bebas) di kalangan remaja. Penelitian yang dilakukan oleh menunjukkan bahwa tidak terdapat hubungan yang signifikan antara peran keluarga terhadap perilaku seksual.

Namun menurut King (dalam Appulembang \& Agustina, 2019 orangtua berperan penting dalam perkembangan anak. Hal yang sama dalam penelitian dilakukan oleh (Haryani \& Haryani, 2015) menunjukkan bahwa terdapat hubungan yang signifikan antara peran orangtua dengan perilaku seks pranikah remaja. Berbeda dengan hasil penelitian yang dilakukan oleh Djannah, Murti, Prabandari \& Anantanyu, (2016) juga menunjukkan bahwa remaja melakukan seks bebas disebabkan karena orangtua yang terlalu fokus dengan pekerjaan, hubungan keluarga yang kurang harmonis, kurang dekat dengan orangtua, tidak pernah melakukan diskusi dengan keluarga. Dengan demikian maka remaja lebih dekat dengan temantemannya dan memperoleh informasi reproduksi dari mereka.

Dengan adanya penelitian ini yang meneliti dari sisi fungsi keluarga maka untuk penelitian selanjutnya dapat dikaitkan dengan teman sebaya. Selain itu dari hasil penelitian ini, peneliti juga menyarankan agar orangtua tetap mengontrol pergaulan anak dengan teman sebayanya.

\section{DAFTAR PUSTAKA}

Afrilyanti, Herlina \& Rahmalia, S, HD (2015). Hubungan Pola Asuh Orangtua Dengan Status Identitas Diri Remaja. JOM, Vol 2 (2).

Appulembang, Y. A \& Agustina ( 2019). Studi Komparatif: Perbedaan Status Identitas Diri Remaja Ditinjau dari Pola Asuh Orangtua Di Unversitas X di Jakarta. Journal Bimbingan dan Konseling Ar- Rahman, Vol 5 (1).

Djannah, S.N., Murti. B., Prabandari, \& Anantanyu. S. (2016). The Reflection of Family Function and Premarital Sex Behavior on Art Community

Gustina, E. ( 2017). Komunikasi Orangtua-Remaja dan Pendidikan Orangtua Dengan Perilaku Seksual Berisiko Pada Remaja. Unnes Journal Of Public Health, 6 (2)

Haryani, D.S., Wahyuningsih, \& Haryani. K (2015). Peran Orangtua Berhubungan dengan Perilaku Seks Pranikah Remaja di SMKN i Sedayu. Jurnal Ners dan Kebidanan Indonesia (JNKI), Vol. 3, No. 3

Hasibuan, R., Dewi. Y. I \& Huda. N (2015). FaktorFaktor yang Mempengaruhi Kejadian Seks Pranikah Pada Remaja Putri Di SMAN I Pagai Utara Selatan Kabupaten Kepulauan Mentawai. Departemen Keperawatan Komunitas Program Studi Ilmu Keperawatan Universitas Riauz

Mertia, E.N., Hidayat, T \& Yuliadi, I ( 2011). Hubungan Antara Pengetahuan Seksualitas Dan Kualitas Komunikasi Orangtua Dan Anak Dengan Perilaku Seks Bebas Pada Remaja Siswa Siswi Man GondangRejo Karangnyar. Wacana Jurnal Psikologi, Vol 2 (2).

Nurhayati, A., Fajar, N.A., \& Yeni (2017). Determinan Perilaku Seksual Pranikah Pada Remaja SMA Negeri I Indralaya Utara. Jurnal Ilmu Kesehatan Masyarakat, Juli 2017, 8(2):83-90

Papalia, D.E., Olds. S. W., \& Feldman. R.D (2009). Human Development. 1oed. McGraw-Hill Education

Putra, I.M.P., Ratep. N., \& Westa, W (2014). Hubungan Antara Peran Keluarga Dengan Perilaku Seksual Pranikah Pada Remaja SMA/Sederajat Di Wilayah Kerja Puskesmas Sukawati I

Rachmawati, C. D \& Devi, S.R ( 2016). Dukungan Sosial Yang Mendorong Perilaku Pencegahan Seks Pranikah Pada Remaja SMA X Di Kota Surabaya. Jurnal Promkes, Vol 4 (2), 129-139.

Rahadi, D.W \& Indarjo, S ( 2017). Perilaku Seks Bebas Pada Anggota Club Motor X Kota Semarang. Jurnal of Health Education JHE 2 (2) http://journal.unnes.ac.id/sju/index.php/jhealt hedu 
Yeni Anna Appulembang, Nur Alam Fajar \& Angeline Hosana Zefany Tarigan, Peran Keluarga dalam Upaya

Rochaniningsih, N. S ( 2014). Dampak Pergeseran Peran dan Fungsi Keluarga Pada Perilaku Menyimpang Remaja. Jurnal Pembangunan Pendidikan: Fondasi dan Aplikasi, Vol 2 ( 1).

Santrock, J. W. (2009). Psikologi Pendidikan: Educational Pyschology (3th ed.). Salemba Humanika

Santrock, J. W. (2011). Adolescence. Boston, USA: McGraw Hill.

Susanti, S., Setyowati, E., Nanik, Rr. (2013). Persepsi Siswa Kelas XI SMK Negeri 4 Surabaya terhadap Perilaku Seks Bebas dikalangan Pelajar Surabaya. IPI, 3 (1): 2.

Tryningtias, D.A (2017). Sex Education. Edisi 1. CV Ae Media Grafika.

Wartati, N. R ( 2012) Upaya Menurunkan Perilaku Seksualitas Remaja Dengan Menggunakan Bimbingan Klasikal Siswa Kelas XIIB Perhotelan SMK Pelita Salatiga. 